\title{
Irrigation Requirements for Grape Crop under Climate Changes Conditions in Egypt
}

\author{
Hashem F. A. ${ }^{1}$, Hassanein, M. K. ${ }^{1}$, Khalil, A. A. ${ }^{1}$, Domokos-Szabolcsy, É. ${ }^{2}$ and Fári M. ${ }^{2}$ \\ ${ }^{1}$ Central laboratory for Agriculture climate, Agriculture Research Center, Dokki, Giza, Egypt \\ ${ }^{2}$ Plant Biotechnology Dept., Debrecen Uni., Böszörményi Ú. 138, 4032 Debrecen, Hungary
}

*Corresponding author: El-Ramady, H. (ramady2000@gmail.com)

\begin{abstract}
Summary: The present work is mainly directed to discuss sensitivity of climate changes upon the irrigation demand for grape crop in Egypt. The Penman Monteith equation was used to calculate reference Evapotranspiration (ET $)$ under current and future climate for the two locations (El Menya and El Beheira). The historical climate data for ten years from (2000 - 2010) was used as current climate to calculate irrigation requirement for grape crop under Egyptian conditions. Two climate changes scenarios have been applied as changes in temperature. The first scenario supposed that increasing in temperature of $1.5^{\circ} \mathrm{C}$ would happen, and the second scenario supposed that increasing of $3.5^{\circ} \mathrm{C}$ would happen to calculate reference Evapotranspiration and irrigation requirement for future climate. The results showed that the evapotranspiration and irrigation requirement for grape crop at El Menya location higher than El Beheira location. Irrigation demand for grape plant under two climate changes scenario will increase in El Menya and El Beheira locations. El Menya location will take the highest irrigation demand under climate changes. Therefore, possible adaptation countermeasures should be developed to mitigate the negative effects of climate changes for the sustainable development of agro-ecosystems in Egypt.
\end{abstract}

Keywords: Climate changes, reference evapotranspiration Irrigation requirements, grape

\section{Introduction}

Grape is a popular fruit for both local consumption and international export in many temperate and tropical countries throughout the world. Grape cultivation reached approximately 7.58 million ha world-wide with a total world production of over 68.3 million tons (FAO, 2011). Grape is the second major fruit crops in Egypt and it is the fourth crop of a great potentiality for export to world markets. Total cultivated grapes area in Egypt reached 64,892 ha producing about 1.196 million ton (Ministry of Agriculture, 2010). According to (Tayel et al. 2008), $50 \%$ of these cultivate areas concentrated in the old lands (Wadi and Delta). The water resources in Egypt are limited. The available water resources in Egypt are restricted to a fixed Nile quota (i.e. 55.5 billion cubic meters) in addition to a deep non-renewable groundwater reservoir and a total annually torrent water of $1.5 \mathrm{BCM}$. The Egyptian water needs are $25 \%$ higher than the available water resources, so it should be rationalized irrigation water. Furthermore, it should be also increased the cultivated lands via modern technology in developing farming irrigation systems in both new and old lands (Allam, 1995). The applied water-yield relationship is more complex. At low levels of applied water, up to about $50 \%$ of full irrigation, yield increases more or less linearly with applied water. Beyond the point of maximum yield, the yield turns downward, reflecting yield losses from anaerobic root zone conditions, disease and leaching of nutrients from excessive water use (Vaux and Pruitt, 1983; Erdem et al. 2006). Meanwhile, Matthews (1990) suggested that optimum growth, grape yield, and grape quality could be obtained by controlling irrigation during certain phenological stages of vine growth.

The recent climatologically studies found that the global surface air temperature had been increased by 0.76 ${ }^{\circ} \mathrm{C}$ from year 1850 to year 2005. Moreover, the linear warming trend over the last 50 years was recorded by 0.13 ${ }^{\circ} \mathrm{C}$ per decade (IPCC, 2007b). Furthermore, there has been an increase in extreme events frequency and intensity in many parts of the world. Regarding the global trends, the recent studies found that the Arab region experienced an uneven increase in surface air temperature ranged from 0.2 to $2{ }^{\circ} \mathrm{C}$ occurred from 1970 to 2004 (IPCC, 2007a). The historical climate data recorded for African shows countries of approximately $0.7^{\circ} \mathrm{C}$ over most of the continent during the twentieth century (Desanker, 2002). Additionally, climate data gathered in North Africa region during the $20^{\text {th }}$ century indicated heating by more than $1{ }^{\circ} \mathrm{C}$, with pronounced trend in the last 40 years (Agoumi, 2001). The climate change impacts on crop water consumption, under Egyptian conditions, have been studied in scattered and limited studies (Eid et al. 1997, El Marsafaway, 2006, Medany and Hassanien 2006, Abou-Hadid, 2006 and 
Hassanien et al. 2007) of these all studies were focusing on specific crops regions in Egypt. Regarding Khalil et al. (2011) the climatic differences between the northern and southern governorates in Egypt. Furthermore, these climate differences implied that under climate changes condition, which is expected to occur in the future, the agriculture production in the southern governorates will be affected by expected heat stress. Although, it is true that higher temperature regimes generally result in the best quality fruits, excessively high temperatures for extended periods of time are known to damage fruits. Excessively higher temperatures generally result in delay of fruit maturation and reduction in quality of grape fruit (Kliewer, 1971, Kliewer and Schultz., 1973).

Therefore, the aim of this study was to investigate the impact of climate changes on water consumptive for grape yield under two Egyptian locations in order to estimate the (ET) changes occurred all over Egypt during the historical time series of 2000-2010.

\section{Material and method:}

The Penman Monteith equation was used to calculate reference Evapotranspiration $\left(\mathrm{ET}_{\mathrm{o}}\right)$ and irrigation requirement for grape plant under current and future climate for the two locations (El Menya and El Beheira).

\section{Current climate}

Daily historical data of minimum, maximum air temperature, relative humidity, wend speeds and solar radiation of two weather satiations of the Central Laboratory for Agriculture Climate (CLAC) were obtained to be calculated and analyzed in order to determine the occurred changes in $\mathrm{ET}_{\mathrm{o}}$ data trends in two locations (El Beheira and El Menya) in Egypt. The coordinates of these locations are in Table 1 between 2000 to 2009. The current ET (average data of 2000-2009) was compared to the ET under two climate change scenarios.

Table 1: Coordinates of weather stations at El Behaira and El Menya locations

\begin{tabular}{|l|c|c|c|}
\hline Station Name & Latitude & Longitude & Elevation $(\mathbf{m})$ \\
\hline El Behaira & $31^{\circ} 02^{\circ}$ & $30^{\circ} 28^{\circ}$ & 6.7 \\
\hline El Menya & $28^{\circ} 05^{\circ}$ & $30^{\circ} 44^{\circ}$ & 40 \\
\hline
\end{tabular}

\section{Future climate}

Two different climate scenarios have been implemented in this work in order to study effects of future climate changes on the Evapotranspiration $\left(\mathrm{ET}_{\mathrm{o}}\right)$ and irrigation water requirement. Scenarios were done by adding $1.5^{\circ} \mathrm{C}$ and $3.5^{\circ} \mathrm{C}$ to the maximum and minimum temperatures for the two locations.

\section{Evapotranspiration $\left(\mathrm{ET}_{\mathrm{o}}\right)$ calculation Penman-Monteith method}

The FAO Penman-Monteith method is recently recommended as the sole standard method when all data required are available (Allen $\boldsymbol{e t}$ al, 1998). It is a method with strong likelihood of correctly predicting $\mathrm{ET}_{\mathrm{o}}$ in a wide range of locations and climates. A panel of experts recommended the adoption of the Penman-Monteith combination method as a new standard for reference evapotranspiration and advised on procedures for calculating the various parameters (Allen et al, 1998).

The FAO Penman-Monteith method to estimate $\mathrm{ET}_{\mathrm{o}}$ is expressed as:

$$
\mathbf{E T}_{\mathbf{o}}=\frac{0.408 \cdot \Delta\left(R_{n}-G\right)+\gamma \cdot \frac{900}{T+273} \cdot u_{2} \cdot\left(e_{s}-e_{a}\right)}{\Delta+\gamma\left(1+0.34 \cdot u_{2}\right)}
$$

Where:

$\mathrm{ET}_{\mathrm{o}}=$ reference evapotranspiration $\left(\mathrm{mm} \mathrm{day}^{-1}\right)$;

$\mathrm{Rn}=$ net radiation at the crop surface $\left(\mathrm{MJ} \mathrm{m}^{-2} \mathrm{Day}^{-1}\right)$;

$\mathrm{G}=$ soil heat flux density $\left(\mathrm{MJ} \mathrm{m}^{-2}\right.$ day $\left.^{-1}\right)$;

$\mathrm{T}=$ mean daily air temperature at $2 \mathrm{~m}$ height $\left({ }^{\circ} \mathrm{C}\right)$;

$\mathrm{U}_{2}=$ wind speed at $2 \mathrm{~m}$ height $\left(\mathrm{m} \mathrm{s}^{-1}\right)$;

$\mathrm{e}_{\mathrm{s}}=$ saturation vapour pressure $(\mathrm{KPa})$;

$\mathrm{e}_{\mathrm{a}}=$ actual vapour pressure $(\mathrm{KPa})$;

$\mathrm{e}_{\mathrm{s}}-\mathrm{ea}=$ saturation vapour pressure deficit $(\mathrm{KPa})$;

$\Delta=$ slope vapour pressure curve $\left(\mathrm{KPa}^{\circ} \mathrm{C}^{-1}\right)$;

$\chi=$ psychrometic constant $\left(\mathrm{KPa}^{\circ} \mathrm{C}^{-1}\right)$

\section{Irrigation water requirement calculation}

Quantity of irrigation water requirements for grape trees for the two locations (El Menya and El Beheira) were calculated using the following equation:

$\mathbf{I R}=\left[\left(\mathrm{ET}_{0} \times \mathrm{Kcx} \mathrm{Kr} \times \mathrm{A} / \mathrm{Ei}\right)+\mathrm{l} . \mathrm{R}\right] \mathrm{I}$

Where:

$\mathrm{IR}=$ Irrigation water requirements, L/vine/interval,

$\mathrm{ET}_{\mathrm{o}}=$ Reference evapotranspiration, $\mathrm{mm} /$ day,

$\mathrm{Kc}=$ Crop coefficient for grape crop,

$\mathrm{Kr}=$ Reduction factor due to ground cover.

$\mathrm{A}=$ Area $\mathrm{m}^{2} /$ vine.

$\mathrm{Ei}=$ Irrigation system efficiency $\%$,

1.R = Leaching requirements, applied according to the relation between soil extract and irrigation water salinity.

Where L.R.= (ECiw / Ecdw) 100 and I = Irrigation interval, days

\section{Result and Discussion Monthly Evapotranspiration (ET) under current climate}

Understanding average monthly $\mathrm{ET}_{\mathrm{o}}$ trend of the studied period (2000-2009) for the two locations were the first step in carrying out this study. Fig. (1) shows the average monthly 


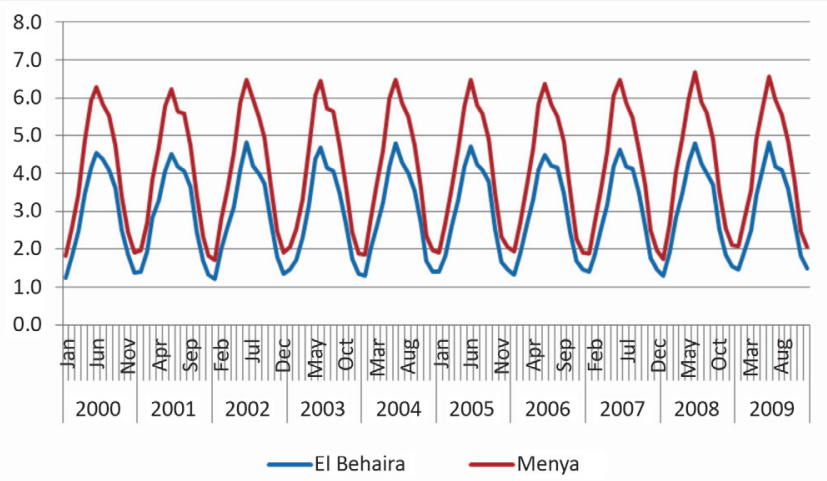

Fig. 1: monthly evapotranspiration $\left(\mathrm{ET}_{\mathrm{o}}, \mathrm{mm} \mathrm{day}^{-1}\right)$ at the two studied weather stations

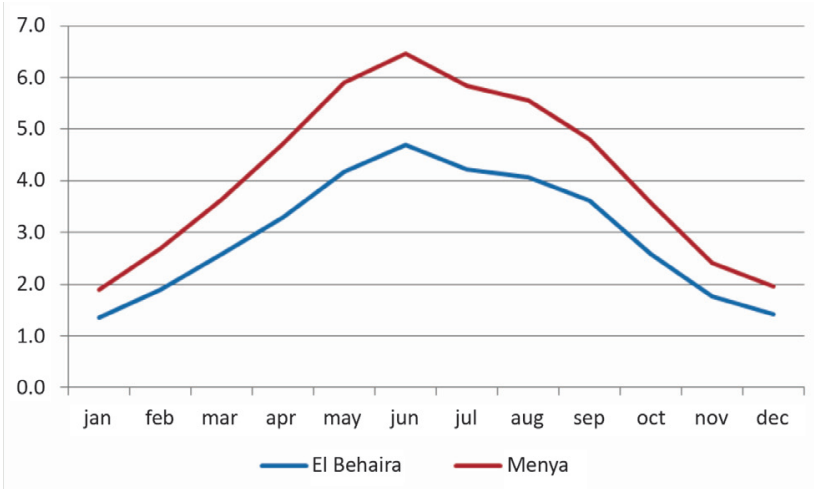

Fig. 2: average monthly evapotranspiration $\left(\mathrm{ETo}, \mathrm{mm} \mathrm{day}^{-1}\right)$ at the two studied weather stations

$\mathrm{ET}$, at the two studied weather stations. El Menya station had recorded the highest monthly ET trends compared to the El Behaira station. The highest $\mathrm{ET}_{\mathrm{o}}$ recorded during 2008 and the lowest ET recorded during 2002. Regarding the average monthly $\mathrm{ET}_{\mathrm{o}}$ of the two stations, the highest values of $\mathrm{ET}_{\mathrm{o}}$ of 4.7 and $6.5 \mathrm{~mm}$ were observed in June at El Behaira and El Menya stations respectively, Fig. (2). In addition, the lowest values of ET of 1.3 and $1.9 \mathrm{~mm}$, were observed in January at El Behaira and El Menya stations respectively.

\section{Monthly Evapotranspiration (ETo) according to climate change scenarios}

The assumptions of two climate change scenarios have been run as changes in maximum and minimum temperature. The first scenario assumption increasing temperature by $1.5^{\circ} \mathrm{C}$ what would happen, the second scenario assumption if temperature increased will be $3.5^{\circ} \mathrm{C}$ what would happen, the Penman-Monteith applying method to predict future impacts of climate change on Evapotranspiration. Increasing temperature will increase Evapotranspiration at both El Behaira and El Menya Table (2). El Menya station had the highest monthly $\mathrm{ET}_{\mathrm{o}}$ trends compared to the El Behaira station. The average monthly ET of the two stations, the highest values of $\mathrm{ET}_{\mathrm{o}}$ were 4.7, 4.9 and $5.1 \mathrm{~mm}$ in June at El Behaira and 6.5, 6.7 and 6.9 at El Menya stations under current and future climate respectively. Meanwhile, the lowest values of ET $1.3,1.4$ and $1.5 \mathrm{~mm}$, in January at El Behaira and 1.9,2 and 2.1 at El Menya station under current and future climate respectively.

\section{Water consumption under El Menya and El Beheira locations}

This data in Table (3) shows that the irrigation requirements for grape should be stopped during dormancy period then start irrigation with blooming stage that, takes into account not oversee water and also plants are not subjected to stress, because it leads to the loss of the crop. After fruit set and fruiting when the fruits were soft should be decrease the water quantity then irrigated it intensive irrigation. After harvesting grape fruits and beginning leafs drop water added till stopped adding water until the plant finish dormancy stage. Similar results were reported by Basinger and Hellman (2006), Zhang and Davies (1989), During et al. (1997), Correia et al. (1995) and Stoll et al. (2000). The effect of different two locations on grape water consumption is present in Table (3). Data shows that the

Table 2: Average monthly evapotranspiration under current and future climate

\begin{tabular}{|c|c|c|c|c|c|c|}
\hline \multirow[t]{2}{*}{ Month } & \multicolumn{3}{|c|}{ El Behaira } & \multicolumn{3}{|c|}{ El Menya } \\
\hline & Current & Current+1.5 & Current+3.5 & Current & Current+1.5 & Current +3.5 \\
\hline January & 1.3 & 1.4 & 1.5 & 1.9 & 2.0 & 2.1 \\
\hline February & 1.9 & 2.0 & 2.1 & 2.7 & 2.8 & 3.0 \\
\hline March & 2.6 & 2.7 & 2.9 & 3.6 & 3.8 & 4.0 \\
\hline April & 3.3 & 3.4 & 3.6 & 4.7 & 4.9 & 5.1 \\
\hline May & 4.2 & 4.3 & 4.6 & 5.9 & 6.1 & 6.4 \\
\hline June & 4.7 & 4.9 & 5.1 & 6.5 & 6.7 & 6.9 \\
\hline July & 4.2 & 4.4 & 4.6 & 5.8 & 6.0 & 6.3 \\
\hline August & 4.1 & 4.2 & 4.4 & 5.5 & 5.7 & 6.0 \\
\hline September & 3.6 & 3.7 & 3.9 & 4.8 & 5.0 & 5.2 \\
\hline October & 2.6 & 2.7 & 2.8 & 3.6 & 3.7 & 3.9 \\
\hline November & 1.8 & 1.8 & 1.9 & 2.4 & 2.5 & 2.7 \\
\hline December & 1.4 & 1.5 & 1.6 & 2.0 & 2.1 & 2.2 \\
\hline Average & 3.0 & 3.1 & 3.2 & 4.1 & 4.3 & 4.5 \\
\hline
\end{tabular}


Table 3: Water requirement for El Beheira and El Menya locations

\begin{tabular}{|l|c|c|}
\hline Month & El Beheira & El Menya \\
\hline January & 0 & 0 \\
\hline February & 0 & 0 \\
\hline March & 170 & 212 \\
\hline April & 255 & 319 \\
\hline May & 361 & 451 \\
\hline June & 428 & 535 \\
\hline July & 383 & 479 \\
\hline August & 468 & 585 \\
\hline September & 406 & 507 \\
\hline October & 276 & 345 \\
\hline November & 160 & 199 \\
\hline December & 0 & 0 \\
\hline Sum & $\mathbf{2 9 0 6}$ & $\mathbf{3 6 3 3}$ \\
\hline
\end{tabular}

highest water consumption was indicated under El Menya location. Total water consumptions of grape plant growing under El Menya location (calculated according to equations in materials and methods) and El Beheira locations were 1513 and $1210 \mathrm{~m}^{3} \mathrm{ha}^{-1}$, respectively, which agreed with the results reported by Allen et al. (1998). Water consumption under El Beheira area is lower than El Menya location, due to the highest air temperatures, the highest relative humidity and the highest light intensity in El Menya location, which led to the increase on water consumption (Khalil et al. 2011).

\section{Water requirement under two climate change scenarios}

The determination of water consumptive $\left(\mathrm{m}^{3} \mathrm{ha}^{-1}\right)$ of grapes plant under two Egyptian locations was obtained by Penman Monteith equation which gave indication about the plant response of the applied water and water balance. This item was affected by grape plant development stages and climatic conditions. The crop water consumptive in the current and future climate change (Table 4) exhibit that the

Table 4: water requirement assumption of two climate change scenarios in two locations

\begin{tabular}{|l|c|c|c|c|}
\hline Month & \multicolumn{2}{|c|}{ El Beheira } & \multicolumn{2}{c|}{ El Menya } \\
\hline Month & Scenario 1.5 & Scenario 3.5 & Scenario 1 & Scenario 3.5 \\
\hline January & 0 & 0 & 0 & 0 \\
\hline February & 0 & 0 & 0 & 0 \\
\hline March & 174 & 178 & 216 & 222 \\
\hline April & 260 & 267 & 327 & 334 \\
\hline May & 369 & 374 & 458 & 467 \\
\hline June & 435 & 444 & 546 & 556 \\
\hline July & 392 & 402 & 490 & 502 \\
\hline August & 476 & 484 & 595 & 605 \\
\hline September & 412 & 421 & 518 & 525 \\
\hline October & 283 & 289 & 353 & 362 \\
\hline November & 162 & 165 & 202 & 205 \\
\hline December & 0 & 0 & 0 & 0 \\
\hline Sum & 2964 & 3024 & 3705 & 3778 \\
\hline
\end{tabular}

actual water consumptive for grape crops was increased according to climate change compared with the actual one in addition to that, it has different regions varied in response to climate changes was also El Menya location will consume the highest irrigation demand under climate changes. The results in Table (4) showed that irrigation requirement for grape at El Menya location higher than El Beheira location. Irrigation demand for grape plant under two climate change scenarios will be increased in El Menya and El Beheira locations. El Menya location will consume the highest irrigation demand according climate changes. From these results, it could be found that, there is a rise in temperature led to a rise in evapotranspiration, causing an increase in water requirements for grape plants under conditions of climate changes the obtained results are in agreement with those of Pouget (1981), Kliewer (1977), Kliewer (1971) and Kliewer and Schultz (1973). Therefore, possible adaptation countermeasures should be developed to mitigate the negative effects of climate change for the sustainable development of agro-ecosystems in Egypt.

\section{Conclusion}

The irrigation requirements were lower in El Beheira than El Menya location. It could be reviewed that, the crop pattern in Egypt and linked the crop pattern with irrigation requirements. Cultivated crops that use a lot of water in areas which have high temperatures, which leads to water loss, but taking into account productivity and quality. The irrigation requirements will be affected with climate changes. The climate change scenarios determinate that in the future, the irrigation requirements will be increasing with increasing air temperature. Therefore, we should focus in water management for grapes yield, high productivity, quality and water efficiency in current and future situation.

\section{References}

Abou- Hadid, A. F. (2006). Assessment of impacts, adaptation and vulnerability to climate change in North Africa: Food production and water resources. A final report submitted to assessments of impacts and adaptations to climate change (AIACC), Project No. AF 90.

Agoumi, A. (2001). Vulnerability studies on three North Africa countries (Algeria, Morocco and Tunisia) with respect to climatic changes, final report of UNEP-GEF project RAB94G31.

Allam, M. N. (1995). "Water Resources in Egypt: Future Challenges and Opportunities" IWRA, Water International, Volume 32, Number 2, June 2007.

Allen, R. G., L. S. Peirera, D. Raes and M. Smith (1998). Crop evapotranspiration guidline for cumputing crop water requirements, irrigation and drainage paper 58, FAO.300 p.

Basinger, A. R. and E. W. Hellman (2006). Evaluation of regulated deficit irrigation on grape in Texas and implications for acclimation and cold hardiness. International Journal of Fruit Science, Vol. 6(2): 3 - 22.

Correia, M. J., J. S. Pereira, M. M. Chaves, M. L. Rodrigues and C. A. Pacheco (1995). ABA xylem concentrations determine 
maximum daily leaf conductance of Field-grown Vitis viniferaL. plants. Plant Cell Environ. 18:511-521.

Desanker, P. V. (2002). Impact of climate change on Africa. WWF special report. http://www.wwf.org.uk/filelibrary/pdf/africa climate text.pdf.

During, H., B. R. Loveys and P. R. Dry (1997). Root signals affect water use efficiency and shoot growth. Acta Hort. 427:1-14.

Eid, H. M., S. M. El-Marsafawy, A. Y. Salib and M. A. Ali (1997). Vulnerability of Egyptian cotton productivity to climate change, Meteorology and Environmental Cases Conference, Cairo, Egypt, 2-6 March.

El-Marsafawy, S. M. (2006). Impact of climate change on sunflower crop production in Egypt. $2^{\text {nd }}$ International Conference on Water Resources \& Arid Environment Proceeding.

Erdem, Y., S. Seshril, T. Erdem and D. Kenar (2006). Determination of crop water stress index for irrigation scheduling of bean (Phaseolus vulgaris L.). Turk J Agric. 30: 195-202.

FAO (2011). FAOSTAT (http://faostat.fao.org/).

Khalil, F., S. Ouda, N. Osman and A. Ghamis 2011). DETERMINATION OF AGRO-CLIMATIC ZONES IN EGYPT USING A ROBUST STATISTICAL PROCEDURE Fifteenth International Water Technology Conference, IWTC-15 2011, Alexandria, Egypt.

Hassanien, M. K. and M. A. Medany (2007). The Impact of Climate Change on Production of Maize (Zea Mays L.), Proc. of the international conference on "climate change and their impacts on costal zones and River Deltas", Alexandria-Egypt, 23-25 April.

IPCC, International Panel of Climate Change (2007a). Climate Change 2007: Impacts, Adaptation and Vulnerability. Contribution of Working Group II to the Fourth Assessment Report of the Intergovernmental Panel on Climate Change, Cambridge University Press, Cambridge, UK, 1000pp.

IPCC (2007b). Climate Change 2007: The Scientific Basis, Summary for Policymakers - Contribution of Working Group I to the IPCC Fourth Assessment Report 2007.
Kliewer, W. M. (1971). Effect of temperature on the composition of cabernet sauvignon berries. American Journal of Enology and Viticulture 22:71-75.

Kliewer, W. M. and H. B. Schultz (1973). Effect of sprinkler cooling of grapevines on fruit growth and composition. American Journal of Enology and Viticulture 24:17-26.

Kliewer, W. M. (1977). Effect of high temperature during the bloom-set period on fruit-set, ovule fertility, and berry growth of several grape cultivars. American Journal of Enology and Viticulture 28:215-221.

Matthews, M. A. (1990). Dependence of wine sensory attributes on vine water status. J. Sci. Food Agric., 51: 321-335.

Medany, M. A. and M. K. Hassanien (2006). Assessment of the impact of climate change and adaptation on potato production. Egyptian Journal of Applied Sciences. Vol. 21 No (11B) 623638.

Ministry of Agriculture of Egypt (2010). Economic Agriculture, Department of Agriculture Economic and Statistics.

Pouget, R. (1981). Action de la temperature sur la differenciaction des inflorescences et dus fleurs durant les phases de pre debourrement et de post debourrement des bourgeons latents de la Vigne. Conn. vigne vin 15:65-79.

Sloll, M., B. Loveys and P. Dry (2000). Hormonal changes induced by partial rootzone drying of irrigated grapevine. J. Expt. Bot. 51:1627-1634.

Tayel, M. Y., A. M. El Gindy and A. A. Abdel-Aziz (2008). Effect of Irrigation Systems On: III-Productivity and Quality of Grape Crop. Journal of Applied Sciences Research, 4(12): 1722-1729.

Vaux, H. J. and W. O. Pruitt (1983). Crop water production functions. Advances in Irrigation, Vol. 2, Daniel Hillel ED. The Academic Press, NY.

Zhang, J. and W. J. Davies (1989). Sequential response of whole plant water relations to prolonged soil drying and the involvement of xylem sap ABA in the regulation of stomatal behavior of sunflower plants. New Phytol. 113:167-174. 